\title{
Antibacterial Activity of Lupinifolin from Derris reticulata and Its Effect on Cytoplasmic Membrane of Methicillin Resistant Staphylococcus aureus ${ }^{\dagger}$
}

\author{
Kamol YUSOOK* and Pettaya PANVONGSA \\ Program of Public Health, Phetchabun Rajabhat University, Phetchabun 67000, Thailand
}

('Corresponding author's e-mail: vetgetmoonlight@hotmail.com)

Received: 9 March 2019, Revised: 15 July 2019, Accepted: 18 August 2019

\begin{abstract}
Lupinifolin from Derris reticulata Craib. was extracted with hexane by Soxhlet extractor and purified by crystallization. The yellow needle-shaped lupinifolin crystals were identified and confirmed by nuclear magnetic resonance (NMR) spectra and Liquid chromatography mass spectrometry (LC/MS). The lupinifolin showed minimum inhibitory concentration (MIC) and minimum bactericidal concentration (MBC) of 8 and $16 \mu \mathrm{g} / \mathrm{ml}$ against Methicillin resistant $S$. aureus (MRSA), respectively. The flow cytometry (FCM) was performed to determine the alteration of cytoplasmic membrane (CM) permeability of MRSA by using Propidium iodide (PI) $5 \mu \mathrm{g} / \mathrm{ml}$ as an indicator for bacterial membrane integrity. It was found that the bacterial CM permeability was effected by lupinifolin with the MIC of 8 $\mu \mathrm{g} / \mathrm{ml}$ comparable to the control when investigated by Propidium iodide intensity. Additionally, DNA laddering assay was carried out to evaluate apoptosis in bacterial cells. It was shown that the lupinifolin has no effect on DNA fragmentation.
\end{abstract}

Keywords: MRSA, Lupinifolin, Cytoplasmic membrane, Derris reticulata

\section{Introduction}

In the past 20 years, the numbers of both community-associated and hospital-acquired infections have increased continuously. Staphylococcus aureus is a major problem in nosocomial infections disease such as pneumonia, operative wound infections and bloodstream infection [1]. Infections caused by $S$. aureus include skin lesions such as boils, furuncles and more serious infections, for example, phlebitis, and meningitis, endocarditis and urinary tract infections. The mortality rate for nosocomial endocarditis is found higher than that for urinary tract infection when the pathogen is S. aureus [2]. The hallmark of staphylococcal infection is the abscess, which consists of a fibrin wall surrounded by inflamed tissues enclosing a central core of pus containing organisms and leukocytes. The organisms may be disseminated hematogenously, even from the smallest abscess. S. aureus has a tendency to spread to particular sites, including the bones, joints, kidneys, and lungs [3]. This may result in virulent sepsis. The presentation of staphylococcal sepsis is similar to that of gram-negative sepsis, with fever, hypotension, tachycardia, and tachypnea. Severe cases progress to multiorgan dysfunction [4], lactic acidosis and death [5].

Many strains of $S$. aureus are developing resistance to available antibacterial agents, creating a serious problem in public health such as methicillin-resistant S. aureus (MRSA). The organism may acquire genes encoding enzymes, moreover $\beta$-lactamase that destroys the antibacterial agent before it can

\footnotetext{
${ }^{\dagger}$ Presented at the International Conferences on Biomedical Sciences and Medical Technology 2019: June 20 - 21, 2019
} 
http://wjst.wu.ac.th

have an effect. For these problems, searching and development of novel antibacterial compounds are urgently required [6].

Flavonoids are well-known and interesting sources for new antibacterial agents. More than 6,000 flavonoid compounds have been purified and identified [7]. They are ubiquitous in photosynthesising cells and are commonly found in fruit, vegetables, nuts, seeds, stems, flowers, tea, wine, propolis and honey. These compounds have been used in traditional herbal medicine as the principal physiologically active constituents to treat human diseases for centuries. In addition, this class of natural products is becoming the subject of antimicrobial research. Many groups of flavonoids possessing antiviral, antifungal or antibacterial activities have been isolated and identified for the structure [8].

Derris plants have received much interest from phytochemical researchers because of their plentiful bioactive compounds of flavonoids. Many Derris flavonoids exhibit wide varieties of biological activities. For example, D. reticulata has been reported to possess anti-diabetic action and antiinflammatory activity [9]. Lupinifolin is the prenylated flavanone that has been isolated from $D$. reticulata Benth. [10], D. reticulata Craib., Myriopteron extensum and Eriosema chinense [11]. There are several lines of evidence demonstrating its antimicrobial potential, including antiviral, antibacterial and antimycobacterial activities [12]. Derris reticulata Craib., a plant in Leguminosae family, contains flavonoids as its major bioactive compound similar to other plants in genus Derris. It is a well-known Thai herbal medicine commonly called as Cha-am-nuea. The picture of this plant is shown in Figure 1. Phytochemicals isolated from some species of Derris plants have been reported to possess biological activities. Three pyranoflavanones, lupinifolin, 2"', 3"' - epoxylupinifolin and dereticulatin were identified from the stems of D. reticulata Benth [13].

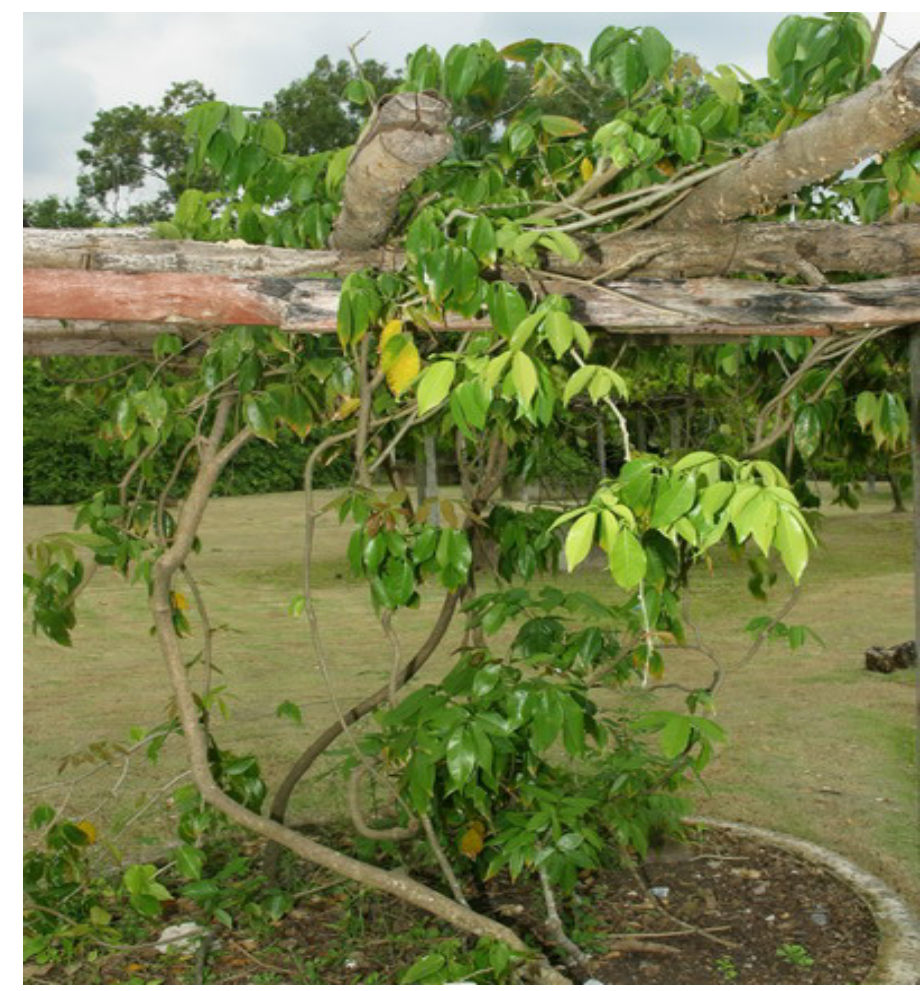

Figure 1 Derris reticulata [14]. 
http://wjst.wu.ac.th

Several studies have demonstrated the mechanisms of action underlying antimicrobial effects of flavonoids extracted from medicinal plants. Because of a variety of the structures in this phytochemical class, the mechanism of action previously established by researchers varies dramatically. For example, sophoraflavanone $\mathrm{G}$ and catechins alter the fluidity of outer and inner layers of bacterial membranes [15]. Antimicrobial activities of the plant flavonoid lupinifolin has been demonstrated, however its mechanism of action has never been documented. Therefore, in the present study, lupinifolin was purified from $D$. reticulata stem. Then screening test for antibacterial activities of lupinifolin against MRSA was performed. Moreover, the pilot study also revealed that lupinifolin caused damage of bacterial cell wall and/or cell membrane. The data obtained from this study will provide scientific evidence to support the use or development of this compound as antimicrobial agent. The possible mechanisms of action were also elucidated.

\section{Materials and methods}

\section{Chemicals}

Hexane, ethanol, methanol, dichrolomethane, $\mathrm{CDCl}_{3}$, tetramethylsilane, $\mathrm{NaCl}$, Mueller-Hinton, $\mathrm{CDCl}_{3}$, glutaraldehyde, acetone and dimethyl sulfoxide were purchased from Carlo Erba (Italy). Propidium iodide (PI), ampicillin and tetracycline were purchased from Sigma-Aldrich (USA).

\section{Plant material and purification of Lupinifolin}

Derris reticulata Craib. was collected from Prachinburi province, Thailand by the former Ph.D. student (Dr. Pakarang Kumkrai). Botanical identification was performed by Dr. Paul J. Grote, School of Biology, Suranaree University of Technology (SUT). A voucher specimen (Pharm-Chu-006) was deposited at School of Pharmacology, SUT. The stems were cut into small pieces and dried at $50{ }^{\circ} \mathrm{C}$ in hot air oven. The dried stems was stored at room temperature until used for extraction.

\section{Determination of constituents of Lupinifolin by LC/MS and NMR}

The structure of lupinifolin was also confirmed from its mass spectrum. The yellow lupinifolin crystal was dissolved in $\mathrm{MeOH}$ (containing $0.1 \%$ formic acid) and injected directly to Electrospay ionization (ESI) source of Bruker micro-TOF-Q mass spectrometer. The ESI source was performed at positive mode, the scan range of mass detector was $50-1,500 \mathrm{~m} / \mathrm{z}$ [16].

The purified lupinifolin was confirmed by NMR spectra on a $500 \mathrm{MHz}$ NMR spectrometer (Bruker AVANE III HD) with a CPP BBO 500 Cyroprobe. Deuterated chloroform $\left(\mathrm{CDCl}_{3}\right)$ was used as solvent and tetramethylsilane (TMS) was used as reference standard. The ${ }^{1} \mathrm{H}$ and ${ }^{13} \mathrm{C}$ NMR spectra was collected at frequencies of 500.366 and 125.83, respectively [13], and was consistent with the published data for lupinifolin.

\section{Antibacterial assays}

\section{Disc diffusion}

Bacteria used in this study was obtained from Thailand Institute of Scientific and Technological Research (TISTR). The antibacterial activities of lupinifolin was evaluated against Gram-positive bacteria Methicillin resistant $S$. aureus (MRSA 4738). The screening of the antibacterial activity was done using disc diffusion method. Bacterial suspensions were prepared by inoculating 1 loopful of a pure colony into Mueller-Hinton Broth (MHB), incubated overnight and diluted in $0.85 \% \mathrm{NaCl}$. Cell suspensions, of which adjusted turbidity equivalent to that of a $0.5 \mathrm{McF}$ arland standard, contains about $10^{8} \mathrm{cfu} / \mathrm{ml}$. These were used to inoculate on Mueller-Hinton Agar (MHA) plates by swabbing over the entire agar surface. Lupinifolin $(20,40 \mu \mathrm{g} / \mathrm{disc})$ was impregnated to filter paper discs (Whatman No.1, $6 \mathrm{~mm}$ diameter) and then placed on the previously inoculated agar plate. After $24 \mathrm{~h}$ of incubation at $37{ }^{\circ} \mathrm{C}$, the antibacterial activity was determined by measuring the diameter of the inhibition zones formed around the disc. Ampicillin and $0.5 \mathrm{~N} \mathrm{NaOH}$ were used as a positive and vehicle controls, respectively [17]. 
http://wjst.wu.ac.th

\section{Determination of minimum inhibitory concentration (MIC) and minimum bactericidal concentration (MBC)}

A modified broth microdilution method according to Clinical and Laboratory Standard Institute Guidelines [18] was used to determine MIC and MBC of lupinifolin. It was dissolved in $0.5 \mathrm{~N} \mathrm{NaOH}$ and 2-fold serial dilutions were made in Mueller-Hinton broth (MHB) using 96-well flat bottom microtiter plate (Corning Life Sciences, USA). Suspension of bacteria in MHB were prepared from the overnight broth culture. The final bacterial cell concentration was adjusted to $5 \times 10^{5} \mathrm{cfu} / \mathrm{ml}$. The final concentration of lupinifolin was ranged from $0.25-512 \mu \mathrm{g} / \mathrm{ml}$. Ampicillin and $0.5 \mathrm{~N} \mathrm{NaOH}$ were used as positive and negative controls, respectively. The MIC was considered as the lowest concentration of the agents showing no visible growth of microorganism after incubation at $37{ }^{\circ} \mathrm{C}$ for $24 \mathrm{~h}$ by spectrometry. The MBC determination was carried out by subculturing $20 \mu \mathrm{l}$ from the broth with no growth onto MuellerHinton Agar (MHA) plates followed by incubation for $24 \mathrm{~h}$ at $37{ }^{\circ} \mathrm{C}$. The lowest concentration with no visible growth was taken as the MBC. All tests were performed in triplicate independent experiments.

\section{Determination of the mechanism of action}

Flow cytometry analysis

Flow cytometry was used to measure membrane integrity [19]. Before each experiment, MRSA was cultured in MHB to reach a midlogarithmic-growth phase. Then, the culture was adjusted to an inoculum of $5 \times 10^{5} \mathrm{cfu} / \mathrm{ml}$. To determine the effects of lupinifolin on bacterial cells, MRSA culture was treated with lupinifolin (MIC $8 \mu \mathrm{g} / \mathrm{ml}$ ) and incubated for 0, 2, 4 and $6 \mathrm{~h}$, respectively. The assay was followed the previously described with some modification [20]. Bacterial suspensions were centrifuged at 8,000 rpm for $15 \mathrm{~min}$ at room temperature and the resulting cell pellets were washed with PBS. Finally, cells were resuspended in PBS and incubated with $5 \mu \mathrm{g} / \mathrm{ml}$ of propidium iodide (PI, Sigma-Aldrich, USA) for 15 min in the dark. PI is generally excluded by intact plasma membrane, thus, uptake of PI (orange/red fluorescence) indicates cell death. Ampicillin and untreated bacterial were included in the experiments as the positive and negative control. The analysis of the cells was performed using flow cytometer (FACScan; BD Biosciences) equipped with a CellQuest software (BD Bioscience).

\section{DNA laddering assay}

MRSA cells $\left(5 \times 10^{5} \mathrm{cfu} / \mathrm{ml}\right)$ were incubated with lupinifolin at MIC and MBC for $8 \mathrm{~h}$. Then genomic DNA of bacteria cells were extracted by using the NucleoSpin Tissue kit (Macherey-Nagel, Germany). The DNA was electrophoresed in $0.7 \%$ agarose gel and visualized by MaestroSafe nucleic acid gel stain reagent (Maestrogen, USA). The gel was photographed under ultraviolet light. Autolysis cells by Triton$\mathrm{X}$ and untreated cells was used as positive and negative controls, respectively [21].

\section{Results and discussion}

The purified lupinifolin was identified by ${ }^{1} \mathrm{H}$ and ${ }^{13} \mathrm{C}$ NMR spectroscopic data as well as the comparison with previously reported data. The spectra of the extracted compound and the lupinifolin were consistent with the published data as shown in Table 1.

Its formula was confirmed by mass spectrometry. The positive mode, $[\mathrm{M}+\mathrm{H}]^{+}$at $\mathrm{m} / \mathrm{z} 407.1850$ (data not showed) which was in accordance with the monoisotopic mass of lupinifolin (406.1780) was recorded. The purity of lupinifolin obtained from this study was more than $95 \%$ based on the NMR spectrum.

Derris plants have received much interest from phytochemical researchers because of their plentiful bioactive compounds of flavonoids [22]. Many of Derris flavonoids exhibit wide varieties of biological activities. For example, D. reticulata has been reported to possess anti-diabetic action and antiinflammatory activity. In the present study, antibacterial were identified by using MIC and MBC. The lupinifolin showed MIC of $8 \mu \mathrm{g} / \mathrm{ml}$ and MBC of $16 \mu \mathrm{g} / \mathrm{ml}$ against MRSA. To investigate the mechanism of action, flow cytometry (FCM), a powerful technique was applied to determine the physiological changes in bacterial cells. FCM is an automated technique with time-saving, accurate and sensitive. Due to a large number of bacterial cells that were processed in a second, statistics were improved. By using 
http://wjst.wu.ac.th

Propidium iodide (PI) $5 \mu \mathrm{g} / \mathrm{ml}$ as an indicator for bacterial membrane integrity, it was found that the bacterial CM permeability was effected by lupinifolin with the MIC of $8 \mu \mathrm{g} / \mathrm{ml}$ comparable to the control (Figure 1). Propidium iodide is used for monitoring intracellular $\mathrm{pH}$, membrane potential, nucleic acid and protein. To corroborate the postulated mechanism that lupinifolin directly acts on bacterial cell membrane, the fluorescent probe PI was used to measure bacterial membrane potentials of MRSA. When exposed to bacterial cells, molecules of PI enter cells and reside either in the membrane or the cytoplasm. The results found from this study appeared similar to curcumin I which was demonstrated to inhibit the growth of $S$. aureus. Curcumin is an important natural component of the rhizome Curcuma longa or turmeric. Propidium iodide uptake and calcein leakage assays were investigated by using flow cytometry technique. It is suggested that its mechanism of action of curcumin I is related to the damaging of bacterial cell membrane, thus impairing the permeabilization of bacterial membranes [23].

Table 1 Comparison of ${ }^{1} \mathrm{H}$ and ${ }^{13} \mathrm{C}$ NMR spectra of the extracted compound and lupinifolin.

\begin{tabular}{|c|c|c|c|c|}
\hline \multirow{2}{*}{ Position } & \multicolumn{2}{|c|}{ Yellow needle-shaped compound ${ }^{\mathrm{a}}$} & \multicolumn{2}{|c|}{ Lupinifolin $^{b}$} \\
\hline & $\delta_{C}(\mathrm{ppm})$ & $\delta_{\mathrm{H}}(\mathrm{ppm})$ & $\delta_{C}(\mathbf{p p m})$ & $\delta_{\mathrm{H}}(\mathrm{ppm})$ \\
\hline 4 & 196.68 & & 196.84 & \\
\hline 7 & 159.75 & & 160.13 & \\
\hline $8 \mathrm{a}$ & 159.53 & & 159.44 & \\
\hline 5 & 157.50 & & 156.48 & \\
\hline $4^{\prime}$ & 156.56 & & 156.09 & \\
\hline $3^{\prime \prime \prime}$ & 130.99 & & 131.11 & \\
\hline $1^{\prime}$ & 129.62 & & 130.60 & \\
\hline $2^{\prime} / 6^{\prime}$ & 127.56 & $7.32(\mathrm{~d}, 8.4)$ & 127.66 & $7.31(\mathrm{~d}, 8.4)$ \\
\hline $3^{\prime \prime}$ & 125.91 & $5.50(\mathrm{~d}, 10.0)$ & 126.02 & $5.52(\mathrm{~d}, 10.1)$ \\
\hline $2^{\prime \prime \prime}$ & 122.56 & $5.14(\mathrm{dd}, 7.2,7.2)$ & 122.40 & $5.16(\mathrm{dd}, 7.2,7.2)$ \\
\hline $4^{\prime \prime}$ & 115.67 & $6.64(\mathrm{~d}, 10.0)$ & 115.53 & $6.64(\mathrm{~d}, 10.1)$ \\
\hline $3^{\prime} / 5^{\prime}$ & 115.67 & $6.87(\mathrm{~d}, 8.4)$ & 115.53 & $6.89(\mathrm{~d}, 8.4)$ \\
\hline 8 & 108.59 & & 108.73 & \\
\hline 6 & 102.70 & & 102.79 & \\
\hline $4 a$ & 102.69 & & 102.61 & \\
\hline 2 & 78.80 & $5.34(\mathrm{dd}, 12.8,2.8)$ & 78.47 & $5.33(\mathrm{dd}, 12.6,3.0)$ \\
\hline $2^{\prime \prime}$ & 78.05 & & 78.20 & \\
\hline $\mathrm{CDCl}_{3}$ & 77.37 & & & \\
\hline $\mathrm{CDCl}_{3}$ & 77.11 & & & \\
\hline $\mathrm{CDCl}_{3}$ & 76.86 & & & \\
\hline \multirow[t]{2}{*}{3} & 43.23 & $3.04(\mathrm{dd}, 17.6,12.8)$ & 42.97 & $3.06(\mathrm{dd}, 17.1,12.6)$ \\
\hline & & $2.80(\mathrm{dd}, 17.6,3.0)$ & & $2.81(\mathrm{dd}, 17.1,3.0)$ \\
\hline $6^{\prime \prime}$ & 28.39 & $1.45(\mathrm{~s})$ & 28.25 & $1.46(\mathrm{~s})$ \\
\hline $5^{\prime \prime}$ & 28.29 & $1.44(\mathrm{~s})$ & 28.33 & $1.45(\mathrm{~s})$ \\
\hline $4^{\prime \prime \prime}$ & 25.80 & $1.65(\mathrm{~s})$ & 25.78 & $1.66(\mathrm{~s})$ \\
\hline $1^{\prime \prime \prime}$ & 21.47 & $3.21(\mathrm{~d}, 7.2)$ & 21.42 & $3.22(\mathrm{~d}, 7.2)$ \\
\hline $5^{\prime \prime \prime}$ & 25.80 & $1.65(\mathrm{~s})$ & 25.78 & $1.66(\mathrm{~s})$ \\
\hline $5-\mathrm{OH}$ & & $12.24(\mathrm{~s})$ & & $12.24(\mathrm{~s})$ \\
\hline
\end{tabular}

${ }^{\mathrm{a}}$ Recorded in $\mathrm{CDCl}_{3}$ at $500 \mathrm{MHz}$ for ${ }^{1} \mathrm{H}-\mathrm{NMR}$ and $125 \mathrm{MHz}$ for ${ }^{13} \mathrm{C}-\mathrm{NMR}$

${ }^{\mathrm{b}}$ Recorded in $\mathrm{CDCl}_{3}$ at $300 \mathrm{MHz}$ for ${ }^{1} \mathrm{H}-\mathrm{NMR}$ and $75.6 \mathrm{MHz}$ for ${ }^{13} \mathrm{C}-\mathrm{NMR}$, cited in (Mahidol et al. 1997) 
http://wjst.wu.ac.th

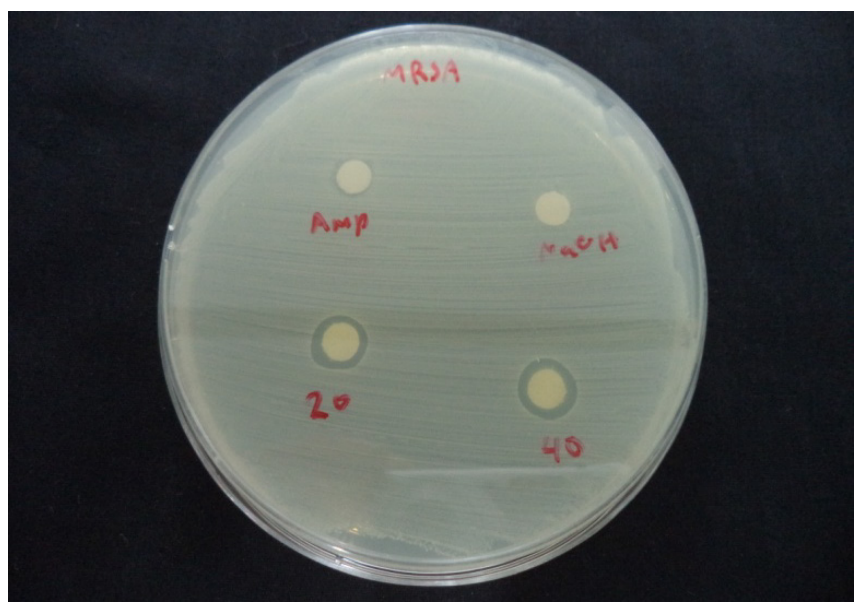

Figure 1 The zone of inhibition of lupinifolin effect on lawn of MRSA.

Table 2 The zone of inhibition of lupinifolin effect on lawn of MRSA.

\begin{tabular}{|c|c|c|c|}
\hline \multirow{3}{*}{ Strain of MRSA } & \multicolumn{3}{|c|}{ Diameter of inhibitions zone (mm) } \\
\hline & \multicolumn{2}{|c|}{ Lupinifolin $(\mu \mathrm{g})$} & \multirow{2}{*}{$\begin{array}{c}\text { Ampicillin }(\mu \mathrm{g}) \\
10\end{array}$} \\
\hline & 20 & 40 & \\
\hline Methicillin resistant S. aureus (MRSA 4738) & $12 \pm 1.1$ & $13 \pm 0.5$ & No inhibition zone \\
\hline
\end{tabular}

Table 3 The minimum inhibitory concentration (MIC) and minimum bactericidal concentration (MBC) of lupinifolin from D.reticulata against MRSA compared with ampicillin.

\begin{tabular}{ccccc}
\hline \multirow{2}{*}{ Microorganisms } & \multicolumn{2}{c}{ Lupinifolin } & \multicolumn{2}{c}{ Ampicillin } \\
\cline { 2 - 5 } & $\mathrm{MIC}(\boldsymbol{\mu g} / \mathbf{m l})$ & $\mathbf{M B C}(\boldsymbol{\mu g} / \mathbf{m l})$ & $\mathbf{M I C}(\boldsymbol{\mu g} / \mathbf{m l})$ & $\mathbf{M B C}(\boldsymbol{\mu g} / \mathbf{m l})$ \\
\hline Methicillin resistant S. aureus $($ MRSA 4738) & 8 & 16 & $>512$ & - \\
\hline
\end{tabular}

Control

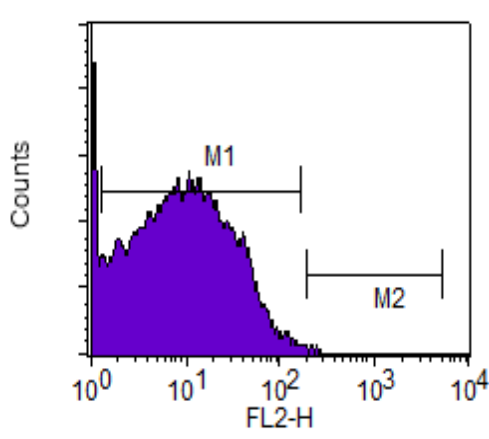

Lupinifolin

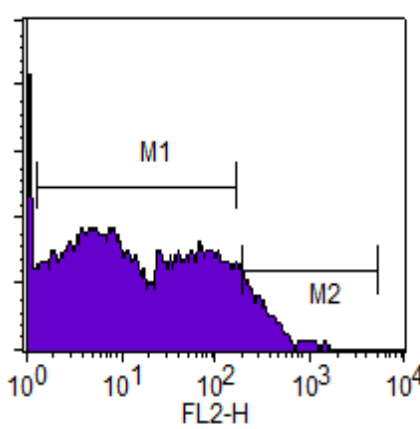

Ampicillin

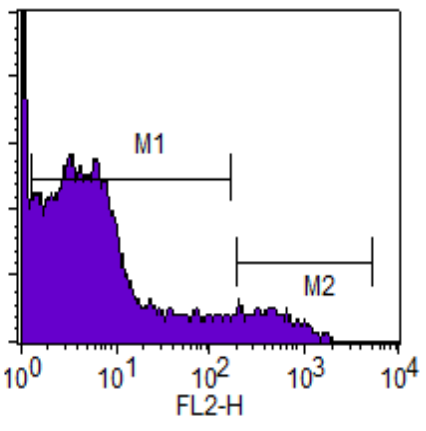

Figure 2 Histograms of Propidium iodide intensity were illustrated of permeability into MRSA by using flow cytometry at emission $544 \mathrm{~nm}$. 


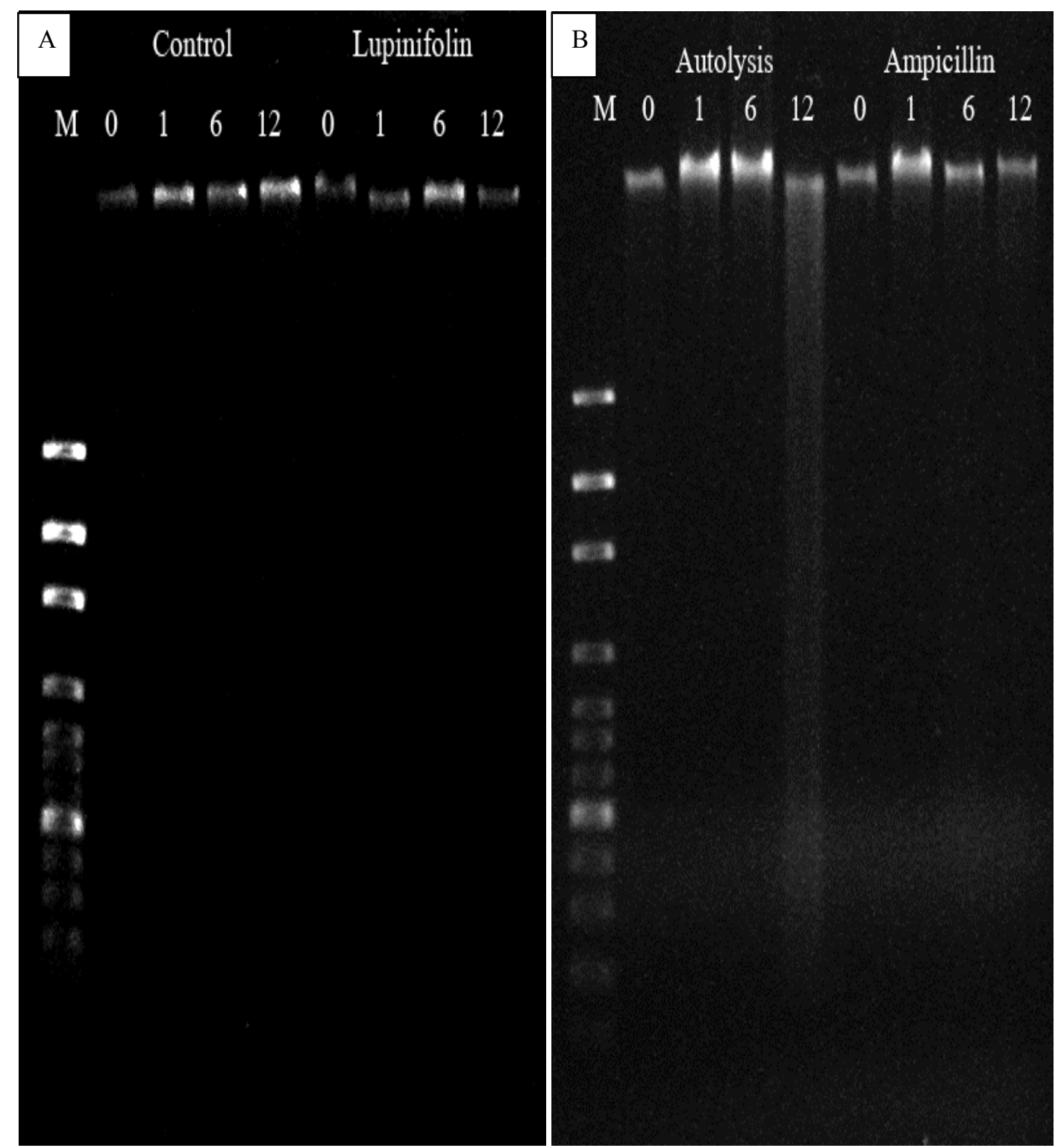

Figure 3 DNA laddering assay. (A): DNA fragments from $S$. aureus cells treated with lupinifolin concentration at $8 \mu \mathrm{g} / \mathrm{ml}$ and untreated cells (control) are incubated for $0,1,6$ and $12 \mathrm{~h}$, respectively. (B): DNA fragments from MRSA cells treated with $0.05 \%$ Triton $\mathrm{X}$ to autolysis and Ampicillin concentration at $0.25 \mu \mathrm{g} / \mathrm{ml}$ are incubated for $0,1,6$ and $12 \mathrm{~h}$, respectively.

In this study, lupinifolin has no effect on apoptosis. The results showed no DNA fragmentation when treated with lupinifolin concentration at $8 \mu \mathrm{g} / \mathrm{ml}$ and compared with untreated cell (Figure 3). DNA laddering assay was carried out to evaluate apoptosis in mammalian cells. It was revealed that the lupinifolin has no effect on DNA fragmentation implying non-genotoxicity of this compound. 
http://wjst.wu.ac.th

\section{Conclusions}

To defeat the opportunistic MRSA, insights regarding the mechanism of action of the antibacterial agent against this bacterium is also needed. According to the results, MIC values of lupinifolin against MRSA strains confirmed the agar disc diffusion test that the lupinifolin can act as an antibacterial agent for antiresistant bacteria. Many publications reported the antibacterial mechanisms of actions of flavonoids, which mostly were the inhibition of cell wall and nucleic acid synthesis including the inhibition of cytoplasmic membrane function [24]. Furthermore, it was suggested that the action of lupinifolin was likely to be the direct disruption of the cytoplasmic membrane [25]. This hypothesis was substantiated by flow cytometry. The results obtained from this study provide direct evidence to support the hypothesis that lupinifolin inhibits bacterial growth of MRSA by damaging the cytoplasmic membrane. The data suggested that lupinifolin may have the potential to be used as antibacterial agent. However, its specific mechanism needs further investigation.

\section{References}

[1] FD Lowy. Staphylococcus aureus infections. New Engl. J. Med.1998; 339, 520-32.

[2] ML Fernandez-Guerrero, C Verdejo, J Azofra and MD Gorgolas. Hospital-acquired infectious endocarditis not associated with cardiac surgery: An emerging problem. Clin. Infect. Dis. 1995; 20, 16-23.

[3] R Ruimy, C Angebault, F Djossou, C Dupont, L Epelboin, S Jarraud and A Andremont. Are host genetics the predominant determinant of persistent nasal Staphylococcus aureus carriage in humans? Int. J. Infect. Dis. 2010; 202, 924-34.

[4] FD Lowy. Staphylococcus aureus infections. N. Engl. J. Med. 1998; 339, 520-32.

[5] R Colgan and JH Powers. Appropriate antimicrobial prescribing: approaches that limit antibiotic resistance. Am. Fam. Phys. 2001; 64, 999-1004.

[6] JM Blair, MA Webber, AJ Baylay, DO Ogbolu and LJ Piddock. Molecular mechanisms of antibiotic resistance. Nat. Rev. Microbiol. 2015; 13, 42-51.

[7] WJH Liu. Traditional Herbal Medicine Research Methods. John Wiley and Sons, Canada, 2011, p. $85-91$.

[8] TP Cushnie and AJ Lamb. Antimicrobial activity of flavonoids. Int. J. Antimicrob. Agents 2005; 26, 343-56.

[9] P Kumkrai, S Kamonwannasit and N Chudapongse. Cytoprotective and anti-diabetic effects of Derris reticulata aqueous extract. J. Physiol. Biochem. 2014; 70, 675-84.

[10] C Mahidol, H Prawat, S Ruchirawat, K Lihkitwitayawuid, LZ Lin and GA Cordell. Prenylated flavanones from Derris reticulata. Phytochemistry 1997; 45, 825-29.

[11] S Chivapat, P Chavalittumrong, A Attiwist and N Soonthornchareonnon. Toxicity study of lupinifolin from stem of Derris reticulata Craib. J. Thai. Trad. Alternat. Med. 2009; 7, 146-55.

[12] N Joycharat, S Thammavong, S Limsuwan, S Homlaead, SP Voravuthikunchai, BE Yingyongnarongkul, S Dej-Adisai and S Subhadhirasakul. Antibacterial substances from Albizia myriophylla wood against cariogenic Streptococcus mutans. Arch. Pharm. Res. 2013; 36, 723-30.

[13] C Mahidol, H Prawat, S Ruchirawat, K Lihkitwitayawuid, LZ Lin and GA Cordell. Prenylated flavanones from Derris reticulata. Phytochemistry 1997; 45, 825-29.

[14] S Ruckhachati. Derris Reticulata Craib. Available at: http://www.pharmacy.mahidol.ac.th/sili, accessed January 2010.

[15] TP Cushnie and AJ Lamb. Recent advances in understanding the antibacterial properties of flavonoids. Int. J. Antimicrob. Agents 2011; 38, 99-107.

[16] SK Prasad, D Laloo, M Kumar and S Hemalatha. Antidiarrhoeal evaluation of root extract, its bioactive fraction, and lupinifolin isolated from Eriosema chinense. Planta Med. 2013; 79, 1620-27.

[17] N Humeera, AN Kamili, SA Bandh, SU Amin, BA Lone and N Gousia. Antimicrobial and antioxidant activities of alcoholic extracts of Rumex dentatus L. Microb. Pathog. 2013; 57, 17-20. 
http://wjst.wu.ac.th

[18] Clinical and Laboratory Standards Institute. Methods for Dilution Antimicrobial Susceptibility Tests for Bacteria that Grow Aerobically, Approved Standard. Clinical and Laboratory Standards Institute Document M07-A8. 2012, p. 16-8.

[19] V Ambriz-Avina, JA Contreras-Garduno and M Pedraza-Reyes. Applications of flow cytometry to characterize bacterial physiological responses. Biomed. Res. Int. 2014; 2014, 461941.

[20] S Ghosh, K Indukuri, S Bondalapati, AK Saikia and L Rangan. Unveiling the mode of action of antibacterial labdane diterpenes from Alpinia nigra (Gaertn.) B. L. Burtt seeds. Eur. J. Med. Chem. 2013; 66, 101-5.

[21] DJ Dwyer, DM Camacho, MA Kohanski, JM Callura and JJ Collins. Antibiotic-induced bacterial cell death exhibits physiological and biochemical hallmarks of apoptosis. Mol. Cell. 2012; 46, 56172.

[22] C Mahidol, H Prawat, V Prachyawarakorn and S Ruchirawat. Investigation of some bioactive Thai medicinal plants. Phytochem. Rev. 2002; 1, 287-97.

[23] P Tyagi, M Singh, H Kumari, A Kumari and Mukhopadhyay. Bactericidal activity of Curcumin I is associated with damaging of bacterial membrane. PLoS One 2015; 10, e0121313.

[24] YJ Eun, MH Foss, D Kiekebusch, DA Pauw, WM Westler, M Thanbichler and DB Weibel. DCAP: A broad-spectrum antibiotic that targets the cytoplasmic membrane of bacteria. J. Am. Chem. Soc. 2012; 134, 11322-25.

[25] K Yusook, O Weeranantanapan, Y Hua, P Kumkrai and N Chudapongse. Lupinifolin from Derris reticulata possesses bactericidal activity on Staphylococcus aureus by disrupting bacterial cell membrane. J. Nat. Med. 2017; 71, 357-66. 